\title{
DIRECT-READING METHODS DALAM ANALISIS PAJANAN NANOPARTIKEL PADA PERSONAL BREATHING ZONE (PBZ) DI INDONESIA : SYSTEMATIC LITERATURE REVIEW
}

\author{
Anita Maria Magdalena Silaban ${ }^{1}$, Mila Tejamaya ${ }^{2}$ \\ Departemen Keselamatan dan Kesehatan Kerja, Fakultas Kesehatan Masyarakat, Universitas \\ Indonesia \\ anita.maria91@ui.ac.id, tejamaya@ui.ac.id
}

\begin{abstract}
The development of using nanoparticles has now greatly increased. Indonesia in 2014 has succeeded in developing electrospinning prototypes that produce nanofibers and nanoparticles. This increase in the utilization of nanoparticles also affects the increase in nanoparticle exposure to workers, which comes from production and incidental activities. Therefore, it is necessary to assess the risk of nanoparticle exposure in the workplace. One of them is the measurement of nanoparticles in the personal breathing zone (PBZ). Measurements can be made by direct-reading (sampler) and indirectreading (monitor) methods. The selection of the method or instrument used in the measurement of nanoparticles can be influenced by the type of nanoparticles, the time of measurement, the method of measurement, to the availability of advanced analytical methods. In view of that, Indonesia as one of the countries that also participates in the use of nanotechnology requires a measurement method that is in accordance with the conditions of the country. The purpose of this study was to gather information about the most suitable direct-reading methods for use in Indonesia. This study uses a systematic literature review research design developed by Kitchenham, and combined with the method developed by Torres-Carion. After following the steps in the SLR, namely Planning, Conducting, and Reporting, 18 studies were found to be carried out for a systematic review. From this study, it was found that the methods that can be used as direct-reading methods in the Personal Breathing Zone (PBZ) are Condensation Particle Counter (CPC) and Optical Particle Counter $(O P C)$. By conducting an assessment in accordance with the conditions of the Indonesian state, this study recommends Condensation particle counter $(C P C)$ as an instrument that can be used.
\end{abstract}

Keywords $\quad$ : Measurement of nanoparticles, personal breathong zone (PBZ), direct reading

\begin{abstract}
ABSTRAK
Perkembangan pemanfaatan nanopartikel saat ini sudah sangat meningkat. Indonesia pada tahun 2014 telah berhasil mengembangkan purnarupa electrospinning yang menghasilkan nanofiber dan nanopartikel. Peningkatan pemanfaatan nanopartikel ini juga berpengaruh terhadap peningkatan pajanan nanopartikel terhadap pekerja, yang berasal dari aktivitas produksi serta insidental. Oleh karena itu, perlu dilakukan upaya penilaian risiko pajanan nanopartikel di tempat kerja. Salah satunya adalah pengukuran nanopartikel pada personal breathing zone (PBZ). Pengukuran dapat dilakukan dengan metode direct-reading (sampler) maupun indirect-reading (monitor). Pemilihan metode atau instrumen yang digunakan dalam pengukuran nanopartikel dapat dipengaruhi oleh jenis nanopartikel, waktu pengukukran, cara pengukuran, hingga ketersediaan metode analisis lanjutan. Mengingat hal tersebut, Indonesia sebagai salah satu negara yang juga turut serta dalam pemanfaatan nanoteknologi membutuhkan metode pengukuran yang sesuai dengan kondisi negaranya. Tujuan dari penelitian ini adalah untuk mengumpulkan informasi mengenai direct-reading methods yang paling sesuai untuk digunakan di Indonesia. Studi ini menggunakan desain penelitian systematic literature review yang dikembangkan oleh Kitchenham, dan dikombinasikan dengan metode yang dikembangkan oleh Torres-carion. Setelah mengikuti tahapan dalam SLR, yaitu Planning, Conducting, dan Report, maka maka ditemukan sebanyak 18 studi yang akan dilakukan tinjauan sistematis. Dari studi tersebut ditemukan metode yang dapat digunakan sebagai direct-reading methods pada Personal Breathing Zone (PBZ) adalah Condensation Particle Counter (CPC) dan Optical Particle Counter (OPC). Dengan melakukan pengkajian sesuai dengan kondisi negara Indonesia, maka penelitian ini merekomendasikan Condensation particle counter (CPC) sebagai instrumen yang dapat digunakan.
\end{abstract}


Kata Kunci : Pengukuran nanopartikel, personal breathing zone (PBZ), direct-reading

\section{PENDAHULUAN}

Nanoteknologi merupakan suatu
aktivitas yang mencakup desain,
karakterisasi, produksi dan penerapan struktur, perangkat, serta sistem dengan mengontrol bentuk dan ukuran pada skala nano (<100 nm) (Albanese et al., 2012). Diketahui bahwa pada tahun 2005 hanya terdapat sebanyak 50 produk konsumen berbasis nanoteknologi, dan pada tahun 2011 terdaftar sebanyak 1300 produk yang meliputi produk kesehatan dan kebugaran, otomotif, makanan, hingga elektronik (Azong-wara et al., 2013). Indonesia juga sedang mengupayakan pemanfaatan nanopartikel. Lembaga Ilmu Pengetahuan Indonesia telah berhasil mengembangankan purnarupa electrospinning untuk menghasilkan nanofiber dan nanopartikel (LIPI, 2014). Keberagaman sumber daya alam Indonesia dapat digunakan menjadi modal utama dalam pengembangan nanoteknologi (Prasetiowati et al., 2018). Merujuk pada Haryanto et al. (2008), jenis industri yang telah mengembangkan teknologi nano dalam aktivitasnya adalah industri keramik dan gelas, pangan, bahan kimia, tekstil, polimer, cat dan pelapis, otomotif, dan elektrik.

Di lingkungan kerja, pajanan nanopartikel terhadap pekerja dapat berasal dari: nanopartikel yang dihasilkan pada proses produksi; dan nanopartikel insidental, misalnya partikel pembakaran, yang dihasilkan dari pengoperasian mesin proses (Organisation for Economic CoOperation and Development, 2017). Stebounova et al. (2018) mengatakan bahwa nanopartikel dapat dihasilkan dari berbagai proses industri, diantaranya adalah pengelasan hingga peleburan logam yang dapat memajani tenaga kerja dan mengendap di seluruh saluran pernapasan, yang dianggap sebagai jalur masuk pengambilan paling kritis (Wiesner et al., 2006), bertranslokasi ke sistem peredaran darah dan menyebar ke berbagai organ tubuh (Stebounova et al., 2018).

Scientific Committee on Emerging and Newly Identifed Health Risk (SCENIHR) mengatakan bahwa penting untuk melakukan penilaian risiko potensial sepanjang siklus hidup produk berbasis nanoteknologi yang membutuhkan informasi mengenai jumlah nanopartikel, luas permukaannya, konsentrasi massa. Organisasi ini juga mengungkapkan bahwa peralatan untuk pengukuran rutin di berbagai media untuk pajanan personal belum adekuat, sehingga perlu dilakukan modifikasi metode penanganan bahaya terkait nanoteknologi (SCENIHR, 2006).

Merujuk pada Asbach et al. (2017), dikatakan bahwa pajanan agen udara termasuk nanopartikel paling baik dinilai dengan mengukur pajanan pada personal breathing zone, yaitu $30 \mathrm{~cm}$ di sekitar mulut dan hidung. Diperlukan instrumen yang kecil dan ringan. Dalam penelitian yang telah dilakukannya juga dikatakan bahwa pengukuran pajanan individu masih belum efektif, dikarenakan kurangnya sampler dan/atau monitor pribadi yang sesuai. Personal exposure measurement ini masih cenderung dilakukan dengan instrumen statis. Tidak banyak sampler dan monitor ini yang tersedia secara komersial dengan komparabilitas, akurasi, dan kegunaannya di lapangan.

Pengukuran pajanan pribadi harus memerhatikan beberapa hal penting, seperti: lokasi (SCENIHR, 2006); instrumen yang digunakan (direct reading atau indirect reading) misalnya yaitu jika pajanan berbasis tugas dengan lonjakan konsentrasi nanopatikel yang berumur pendek, maka dianjurkan untuk menggunakan monitor/direct reading pribadi dengan resolusi waktu tinggi. Namun, untuk penentuan konsentrasi ratarata (misalnya berbasis pergeseran), dapat menggunakan sampler/indirect reading. Jika pajanan pribadi terhadap spesies kimia 
tertentu harus dinilai, maka dapat melakukan pengambilan sampel partikel dan analisis kimia selanjutnya dari deposit. Perlu juga menempatkan instrumen untuk melakukan terhadap "background noise", yaitu nanopartikel yang sudah secara alami di lingkungan kerja (Asbach et al. 2017); karakteristik partikel di lingkungan sekitar, termasuk identifikasi semua sumber nanoaerosol potensial di tempat kerja; sistem ventilasi di tempat kerja untuk menentukan potensi kontaminasi silang; penempatan instrumen, karena karakteristik aerosol dapat berubah dengan jarak dari sumber, menyebabkan variasi spasial dan temporal ukuran nanoaerosol, massa, dan konsentrasi jumlah; interpretasi sumber sampel sumber (Organisation for Economic Co-Operation and Development, 2017).

Banyaknya hal-hal yang harus diperhatikan dalam melakukan pengukuran pajanan pribadi memberikan kebingungan mengenai metode mana yang standar yang dapat dilakukan untuk melakukan personal sampling nanopartikel. Minimnya data dan informasi mengenai metode ini masih menjadi salah satu tantangan dalam mengetahui metode personal sampling nanopartikel. Mengingat situasi ini, maka perlu dilakukan pengkajian secara mendalam mengenai metode yang dapat digunakan sebagai metode standar dalam melakukan personal sampling nanopartikel.

\section{METODE}

Penelitian ini menggunakan metode Systematic Literature Review yang dikembangkan oleh Kitchenham (Kitchenham, 2004), dan dikombinasikan dengan metode yang dikembangkan oleh Torres-carrion (Torres-carrion, 2018). Terdapat dari tiga fase utama, yaitu: Planning, Conducting, dan Report.

Pada tahap planning, bertujuan untuk mengidentifikasikan kebtuhan Sytematic Literature Review dan perumusan protokol penelitaian. Pada sub-tahap identifikasi kebutuhan Systematic Literature Review, akan dirumuskan kebutuhan dilakukan
SLR. Pada penelitian ini, kebutuhan SLR adalah perlunya melakukan pooling data mengenai metode direct-reading methods nanopartikel, sehingga dapat dirumuskan direct-reading methods yang paling sesuai untuk digunakan di Indonesia.

Pada sub-tahap pengembangan protokol, bertujuan untuk mengidentifikasi protokol yang akan dilakukan pada tahapan conducting, meliputi: Identifikasi pertanyaan penelitian, diidentifikasi dari kebutuhan SLR, maka dirumuskan pertanyaan penelitian "Bagaimana metode direct-reading sampel nanopartikel pada Personal Breathing Zone Pekerja di Indonesia?"; Penentuan kriteria inklusi dan eksklusi, Tabel 1 menunjukkan kriteria inklusi dan eksklusi yang akan digunakan dalam pemilihan literatur; Identifikasi SLR terkait, pada sub-tahap ini, pencarian sistematis pertama akan diterapkan dengan merumuskan kata kunci yang akan digunakan terlebih dahulu. Perumusan kata kunci akan didasarkan pada penelusuran tesaurus pada setiap kata. Pada Tabel 2, ditentukan tesaurus dari setiap kata kunci yang akan digunakan dalam pencarian di database; Pemilihan studi, dilakukan dengan cara mengelompokkan studi yang telah terpilih atas pencarian dan filter abstrak sebelumnya. Hanya studi yang terindeks dalam JCR atau JSR saja yang akan dipilih; Uji kualitas studi, Sebagian besar penelitian ilmiah cenderung multidisiplin. Oleh karena itu, uji kualitas studi akan dikaitkan dengan Impact Factor dari jurnal tersebut. Studi akan diranking atas hasil pengkalian antara Impact Factor (IF), Kuartil, SJR dan indeks h5. Dengan rumus sebagai berikut:
"Rank $=(\# r$ studi $* 25 \%)(I F)(S J R)(h 5$ indeks)"

Setelah pengurutan, hanya dua belas jurnal pertama dalam daftar yang harus disimpan, disusun dalam urutan menurun berdasarkan rumus perankingan. 
Tabel 1. Kriteria Inklusi dan Eksklusi

\begin{tabular}{lll}
\hline Kriteria & Inklusi & Eksklusi \\
\hline $\begin{array}{l}\text { Tahun } \\
\text { Publikasi }\end{array}$ & $2000-2021$ & Pre 2000 \\
\hline Bahasa & $\begin{array}{l}\text { Bahasa } \\
\text { Inggris }\end{array}$ & $\begin{array}{l}\text { Selain bahasa } \\
\text { Inggris }\end{array}$ \\
\hline Sumber & Google & Selain Google \\
Informasi & Scholar & Scholar \\
\hline Kriteria & Terindeks & Tidak terindeks \\
tambahan & dalam JCR & dalam JCR atau \\
& atau SJR & JSR \\
\hline
\end{tabular}

Tabel 2. Penelusuran Tesaurus terhadap Kata Kunci

Personal Sampling Nanoparticle

\begin{tabular}{lll}
\hline Nanoparticle & Personal & Sampling \\
\hline Nanoparticle* & Personal & Sampling \\
Nanomaterial & Breathing Zone & \\
Ultrafine Particle & & \\
\hline
\end{tabular}

Tanda bintang (*) di akhir setiap kata digunakan untuk menggeneralisasi simbol apa pun (baik itu huruf, angka, atau karakter khusus) setelah huruf terakhir. Hal ini dapat membuat pencarian lebih efisien. Misalnya pada kata "nanoparticle*", dapat merujuk pada kata nanoparticle maupun nanoparticles. Maka, dalam pencarian pertama dapat menggunakan struktur:

\section{"Nanoparticle* OR Nanomaterial \\ OR Ultrafine Particle AND Personal \\ OR Breathing Zone AND Sampling"}

Penelitian dilakukan dalam rentang tahun 2000 - 2021. Pencarian artikel hanya akan menggunakan Google Scholar saja. Setelah hasil penelusuran awal muncul, maka akan dilakukan tinjauan kualitatif terhadap judul dan abstrak setiap artikel tentang metode personal sampling nanopartikel. Dengan mengikuti pola di atas, maka dalam pencarian Systematic Literature review terkait, dapat menggunakan sintaks seperti berikut ini:

Tabel 3 Sintaks Pencarian Awal untuk Systematic Literature Review pada Metode Personal Sampling Nanopartikel

\begin{tabular}{ll}
\hline Sumber Data & Sintaks \\
\hline Google & Filter Paralel: Tahun $2000-$ \\
Scholar & 2021 \\
& $\begin{array}{l}\text { Anywhere in the article: review, } \\
\text { nanoparticle } * \text { OR }\end{array}$ \\
\hline
\end{tabular}

nanomaterial, OR Ultrafine

Particle, Personal, OR

Breathing Zone, Sampling

Pada tahap conducting, akan dilakukan identifikasi studi, pemilihan studi, hingga uji kualitas studi dengan menggunakan protokol yang telah ditentukan pada tahapan planning.

Tabel 5 menujukkan hasil pencarian studi dengan menggunakan sintak yang telah ditentukan sebelumnya pada google scholar. Dari pencaria awal, ditemukan sebanyak 17.100 studi terkait. Dilanjutkan dengan analisis judul terhadap semua studi, maka ditemukan sebanyak 47 studi yang relevan. Setalh itu, dilakukan analisis abstrak secara mendalam, sehingga dirumuskan terdapat sebanyak 24 studi artikel yang akan masuk ke dalam tahapan selanjutnya.

Setelah dilakukan pemilihan studi, sebanyak 24 studi telah dipilih, lalu diindentifikasi berdasarkan jurnal terbitannya. Hanya jurnal yang telah terindeks dalam JCR atau SJR yang akan dipilih. Tabel 5 menunjukkan daftar studi pilihan. Dari studi yang lolos filter abstrak, jumlah yang telah terindeks dalam JCR atau SJR adalah sebanyak 18 studi. 18 studi ini akan dilakukan uji kualitas serta perankingan. Tabel 5 menunjukkan proses perankingan studi yang telah dipilih pada tahapan sebelumnya.

Tahapan selanjutnya adalah melakukan report studi yang akan dilakukan kajian. Tabel 6 menunjukkan studi pilihan yang telah dilakukan uji kualitas. Terdapat sebanyak 18 studi yang akan dilakukan tinjauan sistematis.

\section{HASIL}

Berdasarkan tinjauan pustaka sistematis terhadap studi terpilih, ditemukan sebanyak 13 jenis instrumen atau metode yang dapat digunakan sebagai metode pengambilan sampel nanopartikel.

Metode atau instrumen yang telah diidentifikasi kemudian dikerucutkan menjadi metode atau instrumen pengukuran 
sampel pada personal breathing zone. Pengidentifikasian ini dirumuskan berdasarkan mobilitas (stasioner atau portabel) instrumen. Dalam Tabel 7. metode diidentifikasi berdasarkan ukuran sampel, direct/indirect reading, dan metric.

Tabel 4 Hasil Pencarian Melalui Google Scholar

\begin{tabular}{lccc}
\multicolumn{1}{c}{ Sintaks } & \multicolumn{3}{c}{ Hasil } \\
\cline { 2 - 4 } & $\begin{array}{c}\text { Penelusuran } \\
\text { Awal }\end{array}$ & $\begin{array}{c}\text { Analisis } \\
\text { Judul }\end{array}$ & $\begin{array}{c}\text { Analisis } \\
\text { Abstrak }\end{array}$ \\
\hline Filter Paralel: (Tahun 2000-2021) & 17,100 & 47 & 24 \\
Anywhere in the article: nanoparticle*, OR Nanomaterial, OR & & \\
Ultrafine Particle, Personal, OR Breathing Zone, Sampling & & \\
\hline
\end{tabular}

Tabel 5 Ranking Jurnal Berdasarkan Impact Factor (IF)

\begin{tabular}{|c|c|c|c|c|c|c|c|}
\hline \multirow{3}{*}{$\begin{array}{c}\text { No. } \\
1 \\
\end{array}$} & \multirow{2}{*}{ Nama Jurnal } & \multicolumn{2}{|c|}{ JCR } & \multirow{3}{*}{$\begin{array}{r}\text { SJR } \\
\text { Q1 }\end{array}$} & \multirow{3}{*}{$\begin{array}{c}\text { h5 } \\
1,795 \\
\end{array}$} & \multirow{2}{*}{\multicolumn{2}{|c|}{ Ranking }} \\
\hline & & \multirow{2}{*}{ IF } & \multirow{2}{*}{$\begin{array}{c}\mathbf{Q} \\
7.137 \\
\end{array}$} & & & & \\
\hline & Science of the Total Environment & & & & & 244 & $2,344,397.45$ \\
\hline 2 & $\begin{array}{l}\text { TrAC - Trends in Analytical } \\
\text { Chemistry }\end{array}$ & 1 & 10.564 & Q1 & 2,283 & 167 & $1,006,910.30$ \\
\hline 3 & $\begin{array}{l}\text { Journal of Environmental } \\
\text { Management }\end{array}$ & 1 & 6.243 & Q1 & 1,441 & 179 & $402,578.29$ \\
\hline 4 & Particle and Fiber Toxicology & 1 & 7.732 & Q1 & 1,748 & 98 & $331,130.63$ \\
\hline 5 & Journal of Nanoparticle Research & 5 & 2.120 & Q2 & 453 & 121 & $145,254.45$ \\
\hline 6 & Journal of Aerosol Science & 1 & 2.883 & Q1 & 852 & 110 & $67,548.69$ \\
\hline 7 & Aerosol Science and Technology & 1 & 2.528 & Q1 & 876 & 109 & $60,345.89$ \\
\hline 8 & Aerosol and Air Quality Research & 1 & 3.337 & Q2 & 866 & 55 & $39,735.33$ \\
\hline 9 & Inhalation Toxicology & 1 & 1.912 & Q2 & 660 & 87 & $27,446.76$ \\
\hline 10 & $\begin{array}{l}\text { Journal of Occupational and } \\
\text { Environmental Hygiene }\end{array}$ & 1 & 1.534 & Q3 & 498 & 57 & $10,886.03$ \\
\hline 11 & $\begin{array}{l}\text { International Journal of } \\
\text { Occupational and Environmental } \\
\text { Health }\end{array}$ & 1 & 1.167 & Q3 & 346 & 52 & $5,249.17$ \\
\hline 12 & $\begin{array}{l}\text { Journal of Physics: Conference } \\
\text { Series }\end{array}$ & 1 & 0.550 & Q4 & 210 & 85 & $2,454.38$ \\
\hline
\end{tabular}

\section{Tabel 6. Daftar Studi Pilihan}

\begin{tabular}{|c|c|c|c|c|}
\hline No. & Judul & Nama Penulis & $\begin{array}{c}\text { Metode } \\
\text { Penelitian }\end{array}$ & Tahun \\
\hline 1 & $\begin{array}{l}\text { A miniature disk electrostatic } \\
\text { aerosol classifier (mini-disk } \\
\text { EAC) for personal } \\
\text { nanoparticle sizers }\end{array}$ & $\begin{array}{l}\text { Li, Lin; Chen, Da Ren; Qi, Chaolog; } \\
\text { Kulkarni, Pramod S. }\end{array}$ & Eksperimen & 2010 \\
\hline 2 & $\begin{array}{l}\text { A review of selected } \\
\text { engineered nanoparticles in } \\
\text { the atmosphere: Sources, } \\
\text { transformations, and } \\
\text { techniques for sampling and } \\
\text { analysis }\end{array}$ & $\begin{array}{l}\text { Majestic, Brian J.; Erdakos, Garnet B.; } \\
\text { Lewandowski, Michael; Oliver, Karen } \\
\text { D.; Willis, Robert D.; Kleindienst, } \\
\text { Tadeusz E.; Bhave, Prakash V. }\end{array}$ & SLR & 2010 \\
\hline 3 & $\begin{array}{l}\text { A strategy for assessing } \\
\text { workplace exposures to } \\
\text { nanomaterials }\end{array}$ & $\begin{array}{l}\text { Ramachandran, Gurumurthy; Ostraat, } \\
\text { Michele; Evans, Douglas E.; Methner, } \\
\text { Mark M.; O’Shaughnessy, Patrick; } \\
\text { D’Arcy, James; Geraci, Charles L.; } \\
\text { Stevenson, Edward; Maynard, Andrew; } \\
\text { Rickabaugh, Keith }\end{array}$ & SLR & 2011 \\
\hline
\end{tabular}




\begin{tabular}{|c|c|c|c|c|}
\hline 4 & $\begin{array}{l}\text { Design and experimental } \\
\text { evaluation of a new } \\
\text { nanoparticle thermophoretic } \\
\text { personal sampler }\end{array}$ & $\begin{array}{l}\text { Azong-Wara, Nkwenti; Asbach, } \\
\text { Christof; Stahlmecke, Burkhard; Fissan, } \\
\text { Heinz; Kaminski, Heinz; Plitzko, Sabine; } \\
\text { Bathen, Dieter; Kuhlbusch, Thomas A.J. }\end{array}$ & Eksperimen & 2013 \\
\hline 5 & $\begin{array}{l}\text { Development of a personal } \\
\text { sampler for evaluating } \\
\text { exposure to ultrafine particles }\end{array}$ & $\begin{array}{l}\text { Furuuchi, Masami; Choosong, } \\
\text { Thitiworn; Hata, Mitsuhiko; Otani, } \\
\text { Yoshio; Tekasakul, Perapong; Takizawa, } \\
\text { Masami; Nagura, Mizuki }\end{array}$ & Eksperimen & 2009 \\
\hline 6 & $\begin{array}{l}\text { Development of a transfer } \\
\text { function for a personal, } \\
\text { thermophoretic nanoparticle } \\
\text { sampler }\end{array}$ & $\begin{array}{l}\text { Leith, David; Miller-Lionberg, Dan } \\
\text { Casuccio, Gary; Lersch, Traci; Lentz, } \\
\text { Hank; Marchese, Anthony; Volckens, } \\
\text { John }\end{array}$ & Eksperimen & 2014 \\
\hline 7 & $\begin{array}{l}\text { Direct-reading methods for } \\
\text { analysis of volatile organic } \\
\text { compounds and nanoparticles } \\
\text { in workplace air }\end{array}$ & $\begin{array}{l}\text { Duarte, Kátia; Justino, Celine I.L.; } \\
\text { Freitas, Ana Cristina; Duarte, Armando } \\
\text { C.; Rocha-Santos, Teresa A.P. }\end{array}$ & Eksperimen & 2014 \\
\hline 8 & $\begin{array}{l}\text { Emission measurement and } \\
\text { safety assessment for the } \\
\text { production process of silicon } \\
\text { nanoparticles in a pilot-scale } \\
\text { facility }\end{array}$ & $\begin{array}{l}\text { Wang, Jing; Asbach, Christof; Fissan, } \\
\text { Heinz; Hülser, Tim; Kaminski, Heinz; } \\
\text { Kuhlbusch, Thomas A.J.; Pui, David } \\
\text { Y.H. }\end{array}$ & Eksperimen & 2012 \\
\hline 9 & $\begin{array}{l}\text { Exposure monitoring of } \\
\text { graphene nanoplatelets } \\
\text { manufacturing workplaces }\end{array}$ & $\begin{array}{l}\text { Lee, Ji Hyun; Han, Jong Hun; Kim, Jae } \\
\text { Hyun; Kim, Boowook; Bello, Dhimiter; } \\
\text { Kim, Jin Kwon; Lee, Gun Ho; Sohn, Eun } \\
\text { Kyung; Lee, Kyungmin; Ahn, Kangho; } \\
\text { Faustman, Elaine M.; Yu, Il Je }\end{array}$ & Eksperimen & 2016 \\
\hline 10 & $\begin{array}{l}\text { From workplace air } \\
\text { measurement results toward } \\
\text { estimates of exposure? } \\
\text { Development of a strategy to } \\
\text { assess exposure to } \\
\text { manufactured nano-objects }\end{array}$ & $\begin{array}{l}\text { Brouwer, Derk; Van Duuren-Stuurman, } \\
\text { Birgit; Berges, Markus; Jankowska, } \\
\text { Elzbieta; Bard, Delphine; Mark, Dave }\end{array}$ & SLR & 2009 \\
\hline 11 & $\begin{array}{l}\text { Inter-comparison of personal } \\
\text { monitors for nanoparticles } \\
\text { exposure at workplaces and in } \\
\text { the environment }\end{array}$ & $\begin{array}{l}\text { Todea, Ana Maria; Beckmann, Stefanie; } \\
\text { Kaminski, Heinz; Bard, Delphine; Bau, } \\
\text { Sébastien; Clavaguera, Simon; } \\
\text { Dahmann, Dirk; Dozol, Hélène; } \\
\text { Dziurowitz, Nico; Elihn, Karine; Fierz, } \\
\text { Martin; Lidén, Göran; Meyer-Plath, } \\
\text { Asmus; Monz, Christian; Neumann, } \\
\text { Volker; Pelzer, Johannes; Simonow, } \\
\text { Barbara Katrin; Thali, Patrick; Tuinman, } \\
\text { Ilse; van der Vleuten, Arjan; Vroomen, } \\
\text { Huub; Asbach, Christof }\end{array}$ & Eklsperimen & 2017 \\
\hline 12 & $\begin{array}{l}\text { Nanoparticle exposure at } \\
\text { nanotechnology workplaces: } \\
\text { A review }\end{array}$ & $\begin{array}{l}\text { Kuhlbusch, Thomas A.J.; Asbach, } \\
\text { Christof; Fissan, Heinz; Göhler, Daniel; } \\
\text { Stintz, Michael }\end{array}$ & SLR & 2011 \\
\hline 13 & $\begin{array}{l}\text { NanoScan SMPS-A novel, } \\
\text { portable nanoparticle sizing } \\
\text { and counting instrument }\end{array}$ & $\begin{array}{l}\text { Tritscher, Torsten; Beeston, Michael; } \\
\text { Zerrath, Axel F.; Elzey, Sherrie; Krinke, } \\
\text { Thomas J.; Filimundi, Eric; Bischof, } \\
\text { Oliver F. }\end{array}$ & Eksperimen & 2013 \\
\hline 14 & $\begin{array}{l}\text { Personal exposure to ultrafine } \\
\text { particles: The influence of } \\
\text { time-activity patterns }\end{array}$ & Buonanno, G.; Stabile, L.; Morawska, L. & Eksperimen & 2014 \\
\hline 15 & $\begin{array}{l}\text { Review of measurement } \\
\text { techniques and methods for } \\
\text { assessing personal exposure } \\
\text { to airborne nanomaterials in }\end{array}$ & $\begin{array}{l}\text { Asbach, Christof; Alexander, Carla; } \\
\text { Clavaguera, Simon; Dahmann, Dirk; } \\
\text { Dozol, Hélène; Faure, Bertrand; Fierz, } \\
\text { Martin; Fontana, Luca; Iavicoli, Ivo; }\end{array}$ & SLR & 2017 \\
\hline
\end{tabular}




\begin{tabular}{lll}
\hline workplaces & $\begin{array}{l}\text { Kaminski, Heinz; MacCalman, Laura } \\
\text { Meyer-Plath, Asmus; Simonow, Barbara; } \\
\text { van Tongeren, Martie; Todea, Ana Maria }\end{array}$ & \\
\hline $16 \quad \begin{array}{l}\text { Sampling and single particle } \\
\text { analysis for the chemical } \\
\text { characterization of fine } \\
\text { atmospheric particulates: } A \\
\text { review }\end{array}$ & Elmes, Michele; Gasparon, Massimo & SLR \\
\hline $\begin{array}{l}\text { Size distributions of aerosols } \\
\text { in an indoor environment with } \\
\text { engineered nanoparticle } \\
\text { synthesis reactors } \text { operating } \\
\text { under different scenarios }\end{array}$ & Sahu, Manoranjan; Biswas, Pratim & 2017 \\
\hline $\begin{array}{l}\text { Workplace air measurements } \\
\text { and likelihood of exposure to } \\
\text { manufactured nano-objects, } \\
\text { agglomerates, and aggregates }\end{array}$ & $\begin{array}{l}\text { Brouwer, Derk H.; Van Duuren- } \\
\text { Sturman, Birgit; Berges, Markus; Bard, } \\
\text { Delphine; Jankowska, Elzbieta; } \\
\text { Mark, Dave }\end{array}$ & Eksperimen \\
\hline
\end{tabular}

Tabel 7. Metode Pengukuran Nanopartikel di Tempat Kerja

\begin{tabular}{|c|c|c|c|c|}
\hline Sampling Method & Sample Size & DR / IR* & Metric & Mobility** \\
\hline Condensation particle counter (CPC) & $10-1000 \mathrm{~nm}$ & DR & Number & $P$ \\
\hline $\begin{array}{l}\text { Electrical low-pressure impactor } \\
\text { (ELPI) }\end{array}$ & $28-10^{4} \mathrm{~nm}$ & DR & Surface, number & $S$ \\
\hline $\begin{array}{l}\text { Fast Mobility Particle Sizer } \\
\text { Spectometers (FMPS) / Engine } \\
\text { Exhaust Particle Sizer (EEPS) }\end{array}$ & $20-500 \mathrm{~nm}$ & DR & Number & $S$ \\
\hline Mini-DiSC & $10-50 \mathrm{~nm}$ & IR & Number & $P$ \\
\hline MOUDI & $\begin{array}{l}10,18,32,56,100 \\
\mathrm{~nm}\end{array}$ & IR & $\begin{array}{l}\text { Mass, number, } \\
\text { surface area, } \\
\text { volume }\end{array}$ & $P$ \\
\hline Nanobadge & $10-4000 \mathrm{~nm}$ & IR & Mass & $P$ \\
\hline $\begin{array}{l}\text { Nanoparticle Respiratory Deposition } \\
\text { (NRD) }\end{array}$ & $<300 \mathrm{~nm}$ & IR & Mass & $P$ \\
\hline $\begin{array}{l}\text { Nanoparticle surface area monitor } \\
(\text { NSAM) }\end{array}$ & $<1 \mu \mathrm{m}$ & DR & Surface & $S$ \\
\hline NanoTracer & $20-120 \mathrm{~nm}$ & IR & Number & $P$ \\
\hline Optical Particle Counter (OPC) & $2 \mathrm{~nm}-1 \mu \mathrm{m}$ & DR & Surface, number & $P$ \\
\hline Partector & $10-10000 \mathrm{~nm}$ & IR & Number & $S$ \\
\hline $\begin{array}{l}\text { Scanning Mobility Particle Sizer } \\
\text { (SMPS) }\end{array}$ & $2-100 \mathrm{~nm}$ & DR & Mass, number & $S$ \\
\hline Thermal precipitator sampler (TPS) & Up to $300 \mathrm{~nm}$ & IR & $\begin{array}{l}\text { Size, chemical } \\
\text { analysis }\end{array}$ & $P$ \\
\hline
\end{tabular}

$* \mathrm{DR}=$ Direct Reading; $\mathrm{IR}=$ Indirect Reading

$* * \mathrm{P}=$ Portable $; \mathrm{S}=$ Stationary

Pada Tabel 7, DR diidentifikasikan sebagai metode direct-reading, sedangkan IR merupakan metode inderect-reading. Daya mobilitas (mobility) suatu metode atau instrumen diidentifikasikan menjadi portable (dapat menempel pada pekerja) dan stationary (hanya dapat mengukur di satu tempat dalam satu waktu).
Dari Tabel 7 dapat diidentifikasikan bahwa metode personal sampling masih didominasi metode indirect reading. Terdapat sebanyak 6 jenis direct reading methods, sedangkan untuk indirect reading methods terdapat sebanyak 7 metode. Dari semua instrumen pengukuran directreading, dipilih instrumen yang bersifat portabel sebagai personal sampling 
methods, dengan rincian pada Tabel 8 . Dari Tabel 7 diketahui bahwa CPC dapat mengukur nanopartikel jenis Silica nanoparticles; iron nanoparticles; silver nanoparticles; Single-walled carbon nanotubes (SWCNTs). Sedangkan untuk OPC, dapat mengukur silver nanoparticles; Single-walled carbon nanotubes (SWCNTs). Sama halnya dengan direct-reading methods, untuk indirect-reading juga mempertimbangkan sifat portabel suatu instrumen. Instrumen yang memenuhi persyaratan tersebut adalah: mini-DiSC, MOUDI, nanobadge, Nanoparticle Respiratory Deposition (NRD), nanotracer, partector, dan Thermal Precipitator Sampler (TPS).

Tabel 8. Direct Reading Personal Sampling Methods

\begin{tabular}{|c|c|c|}
\hline No & Metode & Jenis Nanopartikel \\
\hline 1 & $\begin{array}{l}\text { Condensation } \\
\text { particle counter } \\
\text { (CPC) }\end{array}$ & $\begin{array}{l}\text { Silica NPs; iron } \\
\text { NPs; silver NPs; } \\
\text { Single-walled } \\
\text { carbon nanotubes } \\
\text { (SWCNTs) }\end{array}$ \\
\hline 2 & $\begin{array}{l}\text { Optical Particle } \\
\text { Counter (OPC) }\end{array}$ & $\begin{array}{l}\text { Silver NPs; Single- } \\
\text { walled carbon } \\
\text { nanotubes } \\
\text { (SWCNTs) }\end{array}$ \\
\hline
\end{tabular}

\section{PEMBAHASAN}

\section{Kriteria pemilihan instrumen}

Merujuk pada European Agency for Safety and Health at Work. (2009), berikut ini adalah beberapa acuan dalam pemilihan metode atau instrumen dalam pengambilan sampel nanopartikel pada breathing zone pekerja:

\section{Waktu / Durasi}

Penentuan metode pengambilan sampel berbasis waktu disini bertujuan untuk menyesuaikan dengan lama kerja individu. Jika waktu kerja singkat, maka diharapkan metode atau instrumen yang digunakan adalah metode dengan estimasi waktu pengoperasian sesingkat mungkin.

Kemudahan Penggunaan dan
Ketersediaan

Diupayakan agar metode atau instrumen dapat digunakan oleh semua kalangan tanpa memrlukan keahlian atau pelatihan khusus. Hal ini dapat memengaruhi efekifitas pemakaian. Diharapkan juga kemudahan pemakaian ini diperhatikan hingga proses analisis (HSE report 2004).

\section{Ukuran nanopartikel yang dikehendaki}

Sering kali bahwa ukuran nanopartikel yang ada di tempat kerja masih belum diketahui, oleh karena itu dibutuhkan instrumen yang dapat digunakan untuk menjangkau nanopartikel yang lebih variatif (Methner, 2009). Sifat fisik atau kimia yang terkait dengan nanopartikel yang menjadi dasar pendeteksian nanopartikel pada media tersebut. Kisaran sifat nanopartikel relevansi potensial untuk penilaian risiko menyoroti kebutuhan utama untuk metode yang sangat sensitif. Dimensi khas nanopartikel berada di bawah batas difraksi cahaya tampak, sehingga berada di luar jangkauan untuk mikroskop optik.

\section{Metode Analisis Lanjutan}

Hal ini terkait penetuan kemampuan direct reading atau indirect reading suatu metode. Seperti yang telah dijelaskan, bahwa metode direct reading sampling tidak perlu melakukan manipulasi sampel terlebih dahulu. Metode ini dapat menggambarkan karakteristik sampel dalam satu waktu. Namun, informasi yang diberikan hanya sebatas number concentration, mass concentration, surface area, dan composition. Berbeda apabila melakukan analisis dengan menggunakan alat karakterisasi khusus yang dapat menggambarkan Sifat organoleptis, persen transmitan, porositas, dan karakteristik lainnya. Number concentration, size distribution and surface area concentration pada perhitungan menggunakan metode direct reading cenderung bersifat lebih umum dan tidak membedakan antara nanopartikel dan partikel lain yang berdiameter $<100 \mathrm{~nm}$ (Kuhlbusch, 2010). 
Analisis tambahan penting untuk dipertimbangkan, namun teknik ini memakan waktu dan mahal. Namun, pengukuran seperti yang dijelaskan di atas akan diperlukan jika nanopartikel tunggal dalam matriks kompleks ingin dideteksi dan dijelaskan dapat dilacak ke produk atau memiliki toksisitas tinggi sehingga bahkan partikel tunggal dapat menyebabkan efek kesehatan (misalnya asbes).

\section{Jenis Nanopartikel yang akan diuji}

Nanopartikel dapat dikelompokkan menjadi silica nanoparticles, iron nanoparticles, silver nanoparticle, dan Single-walled carbon nanotubes (SWCNTs). Tidak semua metode atau instrumen memiliki kemampuan dalam mengukur setiap jenis nanopartikel.

\section{Eliminasi "background noise"}

Salah satu tantangan dalam pengukuran nanopartikel di tempat kerja adalah adanya "background noise", yaitu partikel-partikel yang secara alami sudah ada di lingkungan kerja (EU-OSHA, 2009) ataupun nanopartikel yang ada atas aktivitas di luar lingkungan kerja. Background noise ini dapat berupa: nanopartikel atas aktivitas kendaraan di sekitar lingkungan kerja; aktivitas pembakaran; hingga nanopartikel yang berasal dari asap rokok.

Salah satu upaya dalam mengakali hal ini adalah dengan melakukan pemantauan atau pengukuran tersendiri di luar proses pengukuran nanopartikel pada breathing zone pekerja. Ditulis untuk membahas hasil penelitian, kesamaan dan perbedaan dengan penelitian lain yang telah dilakukan serta kemungkinan pengembangan dari penelitian yang dilakukan. Diskusi harus mengeksplorasi pentingnya hasil pekerjaan, bukan mengulanginya. Hindari kutipan dan diskusi literatur yang diterbitkan secara luas. Buat diskusi sesuai dengan hasil, tetapi jangan ulangi hasilnya. Seringkali harus dimulai dengan ringkasan singkat dari temuan ilmiah utama (bukan hasil eksperimen).

Gambaran

\section{Nanoteknologi di Indonesia}

Haryono (2009), menyebutkan bahwa trend pemanfaatan nanopartikel berdasarkan jenis industrinya di Asia Pasifik masih seputar industri kimia, kesehatan dan ilmu hayati, barang kebutuhan sehari-hari, serta otomotif dan tarnsportasi. Sedangkan di Indonesia, konsentrasi pemanfaatannya terdapat pada industri nano-farmasi dan kesehatan, energi, nanobioteknologi, nanomaterial, dan nanoelektronik dan device. Seiring dengan berjalannya waktu, trend ini sedikit berbeda. Perkembangan industri cenderung terletak pada industri logam, mesin, dan elektronik; industri makanan; industri kimia dan farmasi; Industri Kendaraan Bermotor \& Alat Transportasi Lain; dan Industri Mineral Nonlogam (Kementerian Perindustrian, 2020). Beranjak dari hal ini, dapat dilakukan pemetaan risiko pajanan nanopartikel (Tabel 9).

Dari Tabel 9. Dapat dirumuskan bahwa instrumen direct-reading methods nanopartikel pada Personal Breathing Zone di tempat kerja adalah Condensation Particle Counter (CPC).

\section{Condensation Particle Counter (CPC)}

Instrumen ini dapat mengukur number concentration partikel dengan ukuran $10-$ $1000 \mathrm{~nm}$ dengan rentang konsentrasi 0 100000 particles $/ \mathrm{cm}^{3}$, dioperasikan dengan menggunakan baterai. Sistem kerja dari inistrumen ini adalah dengan menarik udara ke dalam tabung saturator, dicampur dengan uap alkohol isopropil hingga menjadi jenuh. Butanol adalah cairan yang paling umum digunakan, karena dapat dengan mudah diuapkan dan mengembun ke permukaan partikel (hampir tidak tergantung pada komposisi partikel) (Asbach et al., 2017). Kemudian aerosol dilewatkan ke dalam tabung kondensor di mana partikel tumbuh sedemikian rupa sehingga terdeteksi oleh fotodetektor saat 
melewati sinar laser (Ramachandran et al., 2011).

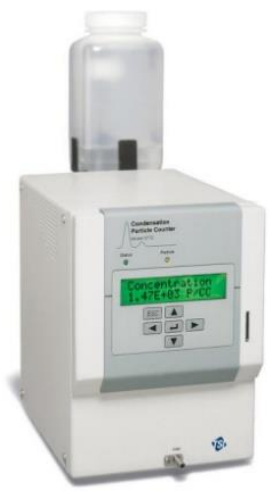

\section{Gambar 1. Condensation particle} counter (CPC)

CPC cukup fleksibel dan cocok digunakan untuk berbagai aplikasi, seperti pengukuran aeorol, pengujian filter dan udara, studi dampak kesehatan partikulat udara terhadap kesehatan, studi yang berkaitan dengan inhalasi dan paparan, studi atmosfer dan iklim (Wardoyo, 2016). Gambar 1 merupakan contoh salah satu tipe Condensation particle counter (CPC). Dimana cara kerjanya meliputi: sampel aerosol ditarik terus menerus melalui saturator dipanaskan di mana butanol diuapkan dan berdifusi ke dalam aliran sampel. Sampel aerosol dan uap butanol masuk ke kondensor yang didinginkan di mana uap butanol menjadi jenuh dan siap untuk mengembun. Proses kondensasi akan terjadi, sehingga ukuran partikel akan membesar. Pompa vakum eksternal diperlukan untuk menarik sampel aerosol ke dalam CPC (TSI, 2015).

Tabel 9. Gambaran Industri dan Risiko Pajanan Nanopartikel di Indonesia

\begin{tabular}{|c|c|c|}
\hline Jenis Industri & $\begin{array}{l}\text { Risiko Pajanan } \\
\text { Nanopartikel }\end{array}$ & Metode atau Instrumen Pengukuran \\
\hline $\begin{array}{l}\text { Industri logam, mesin, } \\
\text { dan elektronik }\end{array}$ & $\begin{array}{l}\mathrm{TiO}_{2}, \mathrm{CuO}, \mathrm{ZnO}, \mathrm{Al}_{2} \mathrm{O}_{3} \\
\mathrm{CNT}\end{array}$ & $\begin{array}{l}\text { Condensation particle counter (CPC); } \\
\text { Optical Particle Counter (OPC); } \\
\text { Nanobadge; } \\
\text { NanoTracer; } \\
\text { Partector; } \\
\text { Thermal precipitator sampler (TPS) }\end{array}$ \\
\hline Industri makanan & $\begin{array}{l}\text { Silver nanoparticles, } \\
\mathrm{ZnO}, \mathrm{TiO}_{2}\end{array}$ & $\begin{array}{l}\text { Condensation particle counter (CPC); } \\
\text { Optical Particle Counter (OPC); } \\
\text { Nanobadge; } \\
\text { NanoTracer; } \\
\text { Partector }\end{array}$ \\
\hline $\begin{array}{l}\text { Industri kimia dan } \\
\text { farmasi }\end{array}$ & $\mathrm{TiO}_{2}, \mathrm{Zn}, \mathrm{ZnO}, \mathrm{Mg}$ & $\begin{array}{l}\text { Condensation particle counter (CPC); } \\
\text { Optical Particle Counter (OPC); } \\
\text { Nanobadge; } \\
\text { NanoTracer; } \\
\text { Partector }\end{array}$ \\
\hline $\begin{array}{l}\text { Industri Kendaraan } \\
\text { Bermotor \& Alat } \\
\text { Transportasi Lain }\end{array}$ & $\mathrm{Fe}, \mathrm{TiO}_{2}$ & $\begin{array}{l}\text { Condensation particle counter (CPC); } \\
\text { Optical Particle Counter (OPC); } \\
\text { Nanobadge; } \\
\text { Nanoparticle Respiratory Deposition (NRD); } \\
\text { NanoTracer; } \\
\text { Partector }\end{array}$ \\
\hline $\begin{array}{l}\text { Industri Mineral } \\
\text { Nonlogam }\end{array}$ & Silica nanoparticles & $\begin{array}{l}\text { Condensation particle counter (CPC); } \\
\text { Mini-DiSC; } \\
\text { MOUDI (nano); } \\
\text { Nanobadge; } \\
\text { NanoTracer; } \\
\text { Partector }\end{array}$ \\
\hline
\end{tabular}

\begin{tabular}{rrrr}
\hline Instrumen ini cukup & userfriendly, \\
dengan ukuran yang & minimalis
\end{tabular}
memudahkan penggunaannya, namun pengukuran dengan menggunakan metode 
ini harus hati-hati dikarenakan pengoperasiannya menggunakan cairan, berupa alkohol, oleh karena itu pada saat pengukuran nanopartikel diharapkan untu tidak memiringkan alat (Duarte, K., et al, 2014). Kelemahan dari instrumen ini adalah mampu menghitung semua partikel dalam aerosol tetapi tidak spesifik ukuran, dan efisiensi penghitungan menurun dengan ukuran partikel, diperlukan juga perawatan cukup intens (diperlukan pengisian ulang cairan kondensasi secara berkala) (Chiu, 2012).

\section{KESIMPULAN}

Dalam pemilihan metode atau instrumen dalam pengukuran nanopartikel pada Personal Breathing Zone (PBZ) membutuhkan beberapa pertimbangan, yaitu: spesifikasi pengukuran; tingkat sesnsitifitas instrumen; userfriendly, berat instrumen, dan tujuan dari pengukuran. Condensation Particle Counter (CPC) merupakan instrumen direct-reading methods untuk pengukuran nanopartikel pada tingkat Personal Breathing Zone (PBZ) di tempat kerja yang sesuai dengan perkembangan industri di Indonesia.

\section{UCAPAN TERIMA KASIH}

Tinjauan sistematis ini dilakukan sebagai upaya untuk mengembangkan upaya perlindungan pekerja atas pajanan nanopartikel di tempat kerja, khususnya bagi pekerja di Indonesia. Penulis berterima kasih kepada Bapak Doni Hikmat Ramdhan, SKM., M.KKK, PhD, Ibu Laksita Ri Hastiti, SKM, M.KKK, Bapak Hanafi Basumi, CIH, CRSO, Ibu Elsye As Safira, SKM., M.KKK, CIH yang sangat berperan penting dalam memberikan pandangan dan masukan pada penelitian ini.

\section{DAFTAR PUSTAKA}

Albanese, A., Tang, P.S., \& Chan, W. C.W. (2012). The effect of nanoparticle size, shape, and surface chemistry on biological systems. Annual Review of Biomedical Engineering, 14, 116.

Asbach, C. et al. (2017). Intercomparison of a Personal CPC and Different Conventional CPCs. Aerosol and Air Quality Research, 17, 11321141.

(2017). Review of measurement techniques and methods for assessing personal exposure to airborne nanomaterials in workplaces. Science of the Total Environment, 603-034, 793-806.

Azong-Wara, N. et al. (2013). Design and experimental evaluation of a new nanoparticle thermophoretic personal sampler. Journal of Nanoparticle Research, 15(4).

Bacca, J., Baldiris, S., Fabregat, R., Graf, S., \& Kinshuk. (2014). Augmented Reality Trends in Education: A Systematic Review of Research and Applications. Educational Technology \& Society, 17 (4), 133-149.

Bakshi, S., He, Z.L., \& Harris, W.G. (2014). Natural nanoparticles: implication for environment and human health. Environmental Science amd Technology: 10.1080/10643389.2014.921975.

Bau, S. et al. (2015). A laboratory study of the performance of the handheld diffusion size classifier (DiSCmini) for various aerosols in the 15-400 nm range. Environmental Science Processes \& Impacts.

Brouwer, D. et al. (2009). From workplace air measurement results toward estimates of exposure? Development of a strategy to assess exposure to manufactured nano-objects. Journal of Nanoparticle Research, 11(8), 1867-1881. 
(2013). Workplace air measurements and likelihood of exposure to manufactured nanoobjects, agglomerates, and aggregates. Journal of Nanoparticle Research, 15(11).

Buonanno, G., Stabile, L., \& Morawska, L. (2014). Personal exposure to ultrafine particles: The influence of time-activity patterns. Science of the Total Environment, 468469, 903-907.

Cena, L.G., Anthony, R.T., \& Peters, T.M. (2011). A personal nanoparticle respiratory deposition (NRD) sampler. Environmental Science \& Technology, 45, 6483-6490.

Chiu, Y., Leong, K., \& Chang, L. (2012). CPC and SMPS Systems of Monitoring Airborne Nanoparticles-Theory and Experiment. Applied Mechanics and Materials, 101-102, 60-66.

Duarte, K. et al. (2104). Direct-reading methods for analysis of volatile organic compounds and nanoparticles in workplace air. TrAC - Trends in Analytical Chemistry, 53, 21-32.

Elmes, M \& Gasparon, M. 2017. Sampling and single particle analysis for the chemical characterization of fine atmospheric particulates: A review. Journal of Environmental Management, 202, 137-150.

European Agency for Safety and Health at Work. (2009). Literture Review: workplace exposure to nanoparticles.

Faure, B. et al. (2017). Assessment of personal exposure to airborne nanomaterials: Evaluation of a novel sampler. Journal of Physics: Conference Series, 838.

Fierro, M. (2000). Particulate matter. Diakses dari file:///L//Air_updates/particulate mattersingspacehtm.

Fierz, M. et al. (2011). Design, Calibration, and Field
Performance of a Miniature Diffusion Size Classifier. Aerosol Science and Technology, 45(1), 110.

Furuuchi, M. et al. (2010). Development of a personal sampler for evaluating exposure to ultrafine particles. Aerosol and Air Quality Research, 10(1), 30-37.

Haryanto, A. et al. (2008). Kondisi terkini penerapan nanoteknologi pada industri di Indonesia. Prosiding Pertemuan Ilmiah Ilmu Pengetahuan dan Teknologi Bahan 2008.

Hernández, R., Fernández, F., \& Baptista, P. (2014). Metodologia de la investigacion, $6^{\text {th }}$ Editio. Mexico: MacGraw-Hill/Interamericana.

Hubbs, A.F. et al. (2013). Nanotechnology: toxicologic pathology, toxicol. Forest Pathology, 41 (2), 395-409.

Kementerian Perindustrian Republik Indonesia. (2020). Rencana strategis kementerian perindustrian tahun 2020-2024.

Kitchenham, B. (2006). Procedure for performing systematic review. Australia: NICTA Technical Report.

Kuhlbusch, T.A.J. et al. (2011). Nanoparticle exposure at nanotechnology workplaces: A review. Particle and Fibre Toxicology, 8, 1-18.

Lee, J.H. et al. (2016). Exposure monitoring of graphene nanoplatelets manufacturing workplaces. Inhalation Toxicology, 28(6), 281-291.

Leith, D. et al. Development of a transfer function for a personal, thermophoretic nanoparticle sampler. Aerosol Science and Technology, 48(1), 81-89.

Lembaga Ilmu Pengetahuan Indonesia. (2014). Peneliti LIPI Kembangkan Alat Penghasil Nanopartikel. Diakses dari 
http://lipi.go.id/berita/single/Penel iti-LIPI-Kembangkan-AlatPenghasil-Nanopartikel/9497.

Lespes, G., Faucher, S., \& Slaveykova, V. (2020). Natural nanoparticles, anthropogenic nanoparticles, where is the frontier? Frontier in Environmental Science, 8(71), 15.

Li, L. et al. (2009). A miniature disk electrostatic aerosol classifier (mini-disk EAC) for personal nanoparticle sizers. Journal of Aerosol Science, 40(11), 982-992.

Majestic, B.J. et al. (2010). A review of selected engineered nanoparticles in the atmosphere: Sources, transformations, and techniques for sampling and analysis. International Journal of Occupational and Environmental Health, 16(4), 488-507.

Modena, M. et al. (2019). Nanoparticles characterization: what to measure? Advanced Materials, 1901556, 1-26. DOI: 10.1002/adma.201901556.

MSP Corporation. (2017). Models 100 and 110-MOUDI ${ }^{\mathrm{TM}}$ Impactors. MSP Corporation.

(2017). Models 100, 110, 115 and 116-MOUDI ${ }^{\mathrm{TM}}$ Impactors. MSP Corporation.

Nanoindex. (2016). Assessment of personal exposure to airborne nanomaterials a guidance document. Diakses dari: https://nanopartikel.info/wpconte nt/uploads/2020/10/NanoIndExGuidanceDocument-2016.pdf.

NIOSH. (2021). Health effect of occupational exposure to silver nanomaterails.

https://doi.org/10.26616/NIOSHP UB2021112.

Organisation for Economic Co-Operation and Development (OECD). (2017). Strategies, techniques and sampling protocols for determining the concentrations of manufactured nanomaterials in air at the workplace. Series on the safety of manufactured nanomaterials, 82.

Peters, T.M. et al. (2016). Assessing and managing exposures to nanomaterials in the workplace. Assessing Nanoparticle Risks to Human Health, 21-44. http://dx.doi.org/10.1016/B978-0323-35323-6.00002-5.

Prasetiowati, A.L., Prasetya, A.T., \& Wardani, S. (2018). Sintesis nanopartikel perak dengan bioreduktor ekstrak daun belimbing wuluh (averrhoa bilimbi 1.) Sebagai antibakteri. Indonesian Journal of Chemical Science, 7, 2.

Ramachandran, G. et al. (2011). A strategy for assessing workplace exposures to nanomaterials. Journal of Occupational and Environmental Hygiene, 8(11), 673-685.

Sahu, M. \& Biswas, P. (2010). Size distributions of aerosols in an indoor environment with engineered nanoparticle synthesis reactors operating under different scenarios. Journal of Nanoparticle Research, 12(3), 1055-1064.

Schulte, P. A. et al. (2009). Issues in the development of epidemiologic studies of workers exposed to engineered nanoparticles. Journal of Occupational and Environmental Medicine, 15, 3.

Scientific Committee on Emerging and Newly Identifed Health Risk (SCENIHR). (2006). The appropriateness of existing methodologies to assess the potential risks associated with engineered and adventitious products of nanotechnologies.

Stebounova, L. et al. (2018). Particle concentration in occupational settings measured with a 
nanoparticle respiratory deposition (NRD) sampler. Annals of Work Exposure and Health, 10, 1-12.

Todea, A.M. et al. (2017). Intercomparison of personal monitors for nanoparticles exposure at workplaces and in the environment. Science of the Total Environment, 605-606, 929-945.

Torres-Carrion, P.V., Rodriguez, G.R., \& González, C.S.G. (2018). Metodology for systematic liteature review applied to engineering and education. Diakses dari https://www.researchgate.net/publ ication/323277902.

Tritscher, T. et al. (2013). NanoScan SMPS-A novel, portable nanoparticle sizing and counting instrument. Journal of Physics: Conference Series, 429(1).

TSI. (2013). Optical particle sizer spectrometer (OPC) model 3330. TSI Incorporated.

(2015). Condensation Particle Counter (CPC) model 3772/3771. TSI Incorporated.

Vance, M.E. et al. (2015). Nanotechnology in the real world: redeveloping the nanomaterial consumer products inventory. Beilstein Journal of Nanotechnology, 6, 1769-1780.

Viitanen, A.K. et al. (2017). Workplace Measurements of Ultrafine Particles-A Literature Review. Annals of Work Exposures and Health, 61(7), 749-758.

Wang, J. et al. (2012). Emission measurement and safety assessment for the production process of silicon nanoparticles in a pilot-scale facility. Journal of Nanoparticle Research, 14(4).

Wardoyo, A.Y.P. (2016). Emisi partikulat kendaraan bermotor dan dampak keseahatan. Malang: UB Press.
Wiesner, M. R. et al. (2006). Assessing the Risks of Manufactured Nanomaterials. Environmental Science \& Technology, 40(14), 4336-4345.

Yu, I.J., Ichihara, G., \& Ahn, K. (2014). Nanoparticle exposure assessment: methods, sampling techniques, and data analysis. Woodhead Publishing Limited. 